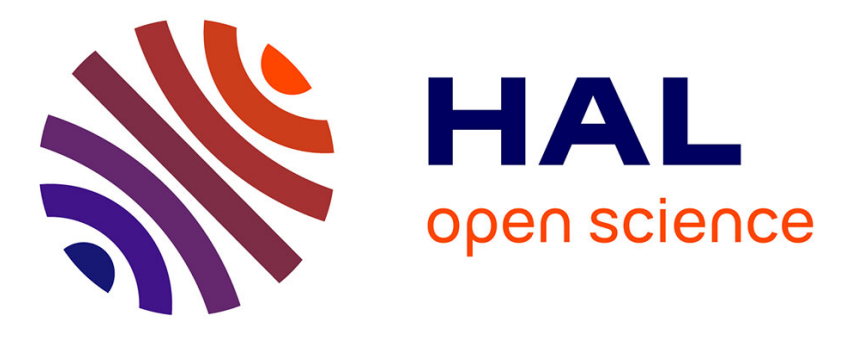

\title{
Polymorphism of the extrapituitary prolactin promoter and systemic sclerosis
}

Markéta Fojtíková, Pavlína Čejková, Radim Bečvář, Jiří Vencovský, Jana

Tomasová Studýnková, Marie Černá

\section{To cite this version:}

Markéta Fojtíková, Pavlína Čejková, Radim Bečvář, Jiří Vencovský, Jana Tomasová Studýnková, et al.. Polymorphism of the extrapituitary prolactin promoter and systemic sclerosis. Rheumatology International, 2009, 30 (12), pp.1691-1693. 10.1007/s00296-009-1284-x . hal-00568314

\section{HAL Id: hal-00568314 https://hal.science/hal-00568314}

Submitted on 23 Feb 2011

HAL is a multi-disciplinary open access archive for the deposit and dissemination of scientific research documents, whether they are published or not. The documents may come from teaching and research institutions in France or abroad, or from public or private research centers.
L'archive ouverte pluridisciplinaire HAL, est destinée au dépôt et à la diffusion de documents scientifiques de niveau recherche, publiés ou non, émanant des établissements d'enseignement et de recherche français ou étrangers, des laboratoires publics ou privés. 
Letter to the Editor

Polymorphism of the extrapituitary prolactin promoter and systemic sclerosis

Authors:

Fojtikova Marketa1 ${ }^{1}$, Cejkova Pavlina ${ }^{2}$, Becvar Radim¹, Vencovsky Jiri¹, Tomasova

Studynkova Jana ${ }^{1}$, Cerna Marie²

\section{Authors affiliation}

1. Institute of Rheumatology, Na Slupi 4, 14800 Prague 2, Czech Republic

2. Department of the General Biology and Genetics, Third Faculty of Medicine, Charles University, Ruska 87, 10000 Prague 10, Czech Republic

3. Department of Anthropology and Human Genetics, Faculty of Science, Charles University Prague, Vinicna 7, 12843 Prague 2, Czech Republic

\section{Corresponding author:}

M. Fojtiková, MD, Institute of Rheumatology, Na Slupi 4, 12850 Prague 2, Czech Republic Email: $\underline{\text { fmar@centrum.cz }}$

Phone number: +420 728890370 Fax number: +420 224914451

Key words: Prolactin, polymorphism, promoter, systemic sclerosis, polymyositis, dermatomyositis

\footnotetext{
Abstract:

Extrapituitary prolactin (PRL) production is regulated by the alternative promoter which contains functional single nucleotide polymorphism -1149 G/T (rs1341239). G allele of this SNP leads to higher mRNA PRL synthesis in lymphocytes. Polymyositis (PM) and systemic sclerosis (SSc) has been associated with increased serum PRL levels and lymphocytes of patients with SSc produce more PRL mRNA. In our association study we tested 75 patients with SSc, 115 patients with polymyositis/dermatomyositis and 123 healthy individuals for -1149 G/T SNP of the extrapituitary PRL promoter. PCR RFLP methodology for allele detection and $x^{2}$ test with Bonferroni correction for statistical evaluation was used in this study. The genotype and allele distribution did not show any variances in groups of PM, DM
} 
and SSc patients compared to healthy individuals. However, we found a significant inverse association between TT genotype in SSc patients with disease onset above 45 years compared to individuals with SSc and diseases onset prior 45 years $(\mathrm{P}$ corrected $=0.02 ; \mathrm{OR}=0.13 ; \mathrm{CI}$ (95\%): 0.02 - 0.69) and healthy subjects (P corrected=0.04; OR 0.2; CI (95\%) 0.04-0.82). TT genotype of the $-1149 \mathrm{G} / \mathrm{T}$ SNP of the extrapituitary PRL promoter decreased a risk for SSc development in older age. Further investigation of the PRL role in SSc pathogenesis is necessary. 
Sirs,

Increased serum prolactin (PRL) levels have been demonstrated in several autoimmune diseases including polymyositis (PM) and systemic sclerosis $(\mathrm{SSc})(1,2,3)$. PRL is produced by the lactotrophs of the pituitary gland, but the immune cells can produce PRL as well, and PRL acts as a cytokine with role in $\mathrm{B}, \mathrm{T}$ and dendritic cells maturation (1). CzuwaraLadykowska et al. demonstrated higher PRL mRNA synthesis in lymphocytes from patients suffering from SSc than in healthy individuals (4). Multiple promoters regulate $P R L$ gene transcription. Unlike the pituitary production controlled by the pituitary promoter under the influence of transcriptional factor Pit-1, the extrapituitary (including that by immune cells) PRL secretion is regulated by the Pit-1 independent alternative promoter located 5.840 bp distal to the start of the PRL transcriptional site (5). This extrapituitary promoter contains functional single nucleotide polymorphism (SNP) -1149 G/T (rs1341239) in the GATA sequence; G allele leads to higher PRL mRNA in lymphocytes synthesis (6). GG genotype has been associated with systemic lupus erythematosus (SLE) $(6,7)$, while TT genotype was identified as protective for non-Hodgkin and follicular lymphoma and rheumatoid arthritis development $(8,9)$.

In this study we looked for distribution of allele and ge notype of the -1149 G/T SNP of the extrapituitary PRL promoter in 75 patients with SSc (average age 61.4), in 47 subjects with PM (average age 57.8) and in 68 DM patients (average age 58.3), and in 123 healthy Czech individuals (blood donors and medical students, average age 39.7). SSc and PM/DM patients met classification criteria for these illnesses $(10,11)$. PCR-RFLP methodology was used for 1149G/T SNP detection (7). Briefly, we amplified 137 bp region of the PRL extrapituitary promoter and for restriction used ApoI endonuclease. We determined genotypes: the homozygote TT characterized by $120 \mathrm{bp}+17 \mathrm{bp}$, the homozygote GG by $85 \mathrm{bp}+35 \mathrm{bp}+17$ bp, and the heterozygote GT by 120 bp +85 bp +35 bp +17 bp DNA fragments. Results were evaluated by $X^{2}$ test with Bonferroni correction. Control group was in Hardy-Weinberg equilibrium.

The genotype and allele distribution did not show any significant differences in groups of PM, DM and SSc patients compared to healthy individuals (Table I) and we detected neither gender distribution differences (data not shown) nor correlation with specific clinical or serological manifestation of these diseases (lung fibrosis, type of scleroderma, antiScl-70 and antiJo-1 positivity) (Table I). However, we found a significant inverse association between TT genotype in SSc patients with disease onset above 45 years compared to individuals with SSc and diseases onset prior 45 years $(2 / 47=4.1 \%$ versus $6 / 18=25 \%$, 
respectively; P corrected $=0.02 ; \mathrm{OR}=0.13$; CI (95\%): 0.02 - 0.69). Similar results were obtained when compared TT genotype in patients with SSc onset after the age of 45 and healthy subjects (P corrected=0.04; OR 0.2; CI (95\%) 0.04-0.82), see Table I.

Thus, genotype -1149 TT of the extrapituitary PRL promoter SNP (via reduced PRL promoter activity and consequently lower PRL levels in lymphocytes) seems to be associated with decreased risk to SSc development in older age. On the other hand, any genotype or allele differences in patients with polymyositis and dermatomyositis according to the age of manifestation onset were found (data not shown). We can assume that this polymorphism might be somewhat specific for SSc and therefore warrants further investigation of prolactin genetics and its levels during the disease course.

Acknowledgement:

This study was supported by the grant of the Czech Ministry of Health: NR/9292 - 3

References:

1. Orbach H, Zandman-Goddard G, Amital H, et al. (2007) Novel biomarkers in autoimmune diseases - prolactin, ferritin, vitamin D, and TPA levels in autoimmune diseases. Ann NY Acad Sci 1109: 385-400.

2. La Montagna G, Meli R, Criscuolo T, et al. (2004) Bioactivity of prolactin in systemic sclerosis. Clin Exp Rheumatol 22:145-150.

3. Mirone L, Barini A, Barini A. (2006) Androgen and prolactin (Prl) levels in systemic sclerosis (SSc) Relationship to disease Severiny. Ann NY Acad Sci 1069: 257-262

4. Czuwara-Ladykowska J, Sicinska J, Olsewska M, et al. (2006) Prolactin synthesis by lymphocytes from patiens with systemic sclerosis. Biomed Pharmacother 60: 152-155.

5. Gellersen B, Kempf R, Telgmann R, et al. (1994) Nonpituitary human prolactin gene transcription is independent of Pit-1 and differentially controlled in lymphocytes and in endometrial stroma. Moll Endocrinol 8: 356-73.

6. Stevens A, Ray DW, Worthington J, et al. (2001) Polymorphisms of the human prolactin gene - implications for production of lymphocyte prolactin and systemic lupus erythematosus. Lupus 10:676-683. 
7. Fojtikova M, Cerna M, Cejkova P, et al. (2007) Extrapituitary prolactin promoter polymorphism in Czech patients with systemic lupus erythematosus and rheumatoid arthritis. Ann Rheum Dis 66: 706-7.

8. Skibola CF, Bracci PM, Paynter RA, et al. (2005) Polymorphisms and haplotypes in the cytochrome P450 17A1, prolactin, and catechol-O-methyltransferase genes and non-Hodgkin lymphoma risk. Cancer Epidemiol Biomarkers Prev 14:2391-2401.

9. Lee YC, Raychaudhuri S, Cui J, et al. (2009) The PRL -1149 G/T polymorphism and rheumatoid arthritis susceptibility. Arthritis Rheum. 60:1250-1254.

10. SUBCOMMITTEE FOR SCLERODERMA CRITERIA OF THE AMERICAN RHEUMATISM ASSOCIATION DIAGNOSTIC AND THERAPEUTIC CRITERIA COMMITTEE (1980) Preliminary criteria for the classification of systemic sclerosis (scleroderma). Arthritis Rheum 23: 581-590.

11. Bohan A, Peter JB. Polymyositis and dermatomyositis (First of two parts) (1975) N Engl J Med 292:344-347. 
Table I.

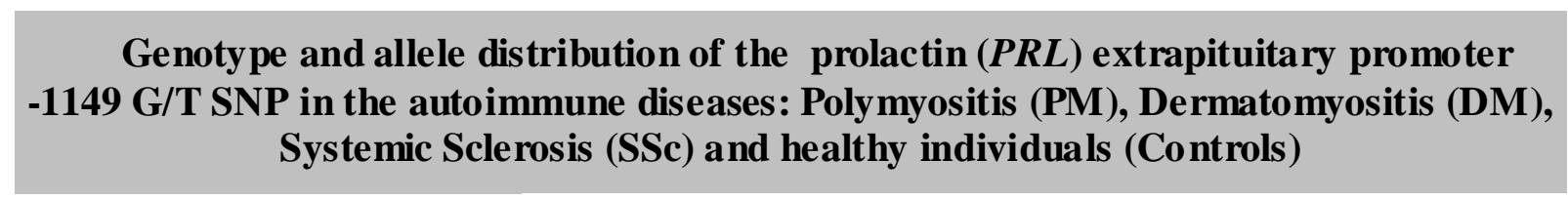

\begin{tabular}{|c|c|c|c|c|c|c|}
\hline \multirow{3}{*}{$\begin{array}{l}\text { Characterization of } \\
\text { tested groups }\end{array}$} & & \multicolumn{5}{|c|}{$P R L$ extrapituitary promoter -1149 G/T SNP } \\
\hline & & \multicolumn{3}{|c|}{ Genotype } & \multicolumn{2}{|c|}{ Allele } \\
\hline & & GG & GT & TT & $\mathbf{G}$ & $\mathbf{T}$ \\
\hline \multirow[t]{2}{*}{$\mathbf{P M}$} & $\begin{array}{l}\mathrm{n}=47 \\
(\%)\end{array}$ & $\begin{array}{c}20 \\
(42.5)\end{array}$ & $\begin{array}{c}21 \\
(44.7)\end{array}$ & $6(12.8)$ & $61(64.9)$ & $33(35.1)$ \\
\hline & $P_{1}$ & $n s$ & $n s$ & $n s$ & $n s$ & $n s$ \\
\hline Jo- 1 positive $(34.0 \%)$ & $\%\left(P_{2}\right)$ & $\begin{array}{l}37.5 \\
(\mathrm{~ns}) \\
50.0\end{array}$ & $\begin{array}{l}56.3 \\
(\mathrm{~ns}) \\
50.0\end{array}$ & $6.2(\mathrm{~ns})$ & $65.6(\mathrm{~ns})$ & $34.4(\mathrm{~ns})$ \\
\hline $\mathrm{CPM}(4.3 \%)$ & $\%\left(P_{2}\right)$ & (ns) & $(\mathrm{ns})$ & $0(\mathrm{~ns})$ & 75 (ns) & 25 (ns) \\
\hline \multirow[t]{2}{*}{$\mathbf{D M}$} & $\begin{array}{c}\mathrm{n}=68 \\
(\%)\end{array}$ & $\begin{array}{c}19 \\
(27.9)\end{array}$ & $\begin{array}{c}35 \\
(51.5)\end{array}$ & $14(20.6)$ & $73(53.7)$ & $63(46.3)$ \\
\hline & $P_{1}$ & $n s$ & $n s$ & $n s$ & $n s$ & $n s$ \\
\hline $\begin{array}{l}\text { Jo- } 1 \text { positive }(19.1 \%) \\
\text { CDM }(13.2 \%)\end{array}$ & $\begin{array}{l}\%\left(P_{2}\right) \\
\%\left(P_{2}\right)\end{array}$ & $\begin{array}{l}15.5 \\
\text { (ns) } \\
22.2 \\
\text { (ns) }\end{array}$ & $\begin{array}{l}46.1 \\
(\mathrm{~ns}) \\
55.6 \\
(\mathrm{~ns})\end{array}$ & $38.4(\mathrm{~ns})$ & $\begin{array}{c}38.5 \\
\left(0.03^{\mathrm{a}}\right)\end{array}$ & $\begin{array}{c}61.5 \\
\left(0.03^{\mathrm{b}}\right) \\
50(\mathrm{~ns})\end{array}$ \\
\hline \multirow[t]{2}{*}{ SSc } & $\begin{array}{l}\mathrm{n}=75 \\
(\%)\end{array}$ & $\begin{array}{c}31 \\
(41.3)\end{array}$ & $\begin{array}{c}36 \\
(48.0)\end{array}$ & $8(10.7)$ & $98(65.3)$ & $52(34.7)$ \\
\hline & $P_{1}$ & $n s$ & $n s$ & $n s$ & $n s$ & $n s$ \\
\hline $\begin{array}{l}\text { Scl-70 positive } \\
(45.2 \%)\end{array}$ & $\boldsymbol{\%}\left(P_{2}\right)$ & $\begin{array}{l}51.5 \\
(\mathrm{~ns})\end{array}$ & $\begin{array}{l}42.4 \\
\text { (ns) }\end{array}$ & $6.1(\mathrm{~ns})$ & 72.7 (ns) & $27.3(\mathrm{~ns})$ \\
\hline $\begin{array}{l}\text { Lung Fibrosis } \\
(40.3 \%)\end{array}$ & $\%\left(P_{2}\right)$ & $\begin{array}{l}41.4 \\
(\mathrm{~ns}) \\
46.3\end{array}$ & $\begin{array}{l}51.7 \\
(\mathrm{~ns}) \\
48.8\end{array}$ & $6.9(\mathrm{~ns})$ & $67.2(\mathrm{~ns})$ & $32.8(\mathrm{~ns})$ \\
\hline $1 \mathrm{SSc}(54.6 \%)$ & $\%\left(P_{2}\right)$ & $\begin{array}{l}(\mathrm{ns}) \\
34.5\end{array}$ & $\begin{array}{l}\text { (ns) } \\
48.3\end{array}$ & $4.9(0.03)$ & $70.7(\mathrm{~ns})$ & $29.3(\mathrm{~ns})$ \\
\hline $\mathrm{dSSc}(38.6 \%)$ & $\%\left(P_{2}\right)$ & (ns) & (ns) & $17.2(\mathrm{~ns})$ & $58.7(\mathrm{~ns})$ & 41.3(ns) \\
\hline $\begin{array}{l}\text { Onset after } 45 \text { years } \\
(65.3 \%)\end{array}$ & $\begin{array}{c}\% \\
\left(P_{2}\right) \\
\end{array}$ & $\begin{array}{l}40.8 \\
(\mathrm{~ns})\end{array}$ & $\begin{array}{l}55.1 \\
(\mathrm{~ns})\end{array}$ & $\begin{array}{c}4.1 \\
\left(0.007^{\mathrm{d}} ; 0.01^{\mathrm{e}}\right)\end{array}$ & $68.3(\mathrm{~ns})$ & $31.3(\mathrm{~ns})$ \\
\hline Controls & $\begin{array}{c}\mathrm{n}=123 \\
(\%)\end{array}$ & $\begin{array}{c}49 \\
(39.8)\end{array}$ & $\begin{array}{c}51 \\
(41.5)\end{array}$ & $23(18.7)$ & 149 (60.6) & $97(39.4)$ \\
\hline
\end{tabular}
a) $\mathrm{P}$ value is defined when compare Jo-1positive DM and healthy controls. Pc. $=0.06$, ns
b) $\mathrm{P}$ value is defined when compare Jo-1positive DM and healthy controls. Pc. $=0.06$, ns
c) $\mathrm{P}$ value is defined when compare SSc patients with limited disease compare to controls, $\mathrm{Pc}=0.09, \mathrm{~ns}$
d) $\mathrm{P}$ value is defined when compare SSc patients with disease onset before and after 45 years.
$\mathrm{Pc}=0.02$; OR 0.13 ; CI(95\%) 0.02-0.69
e) $\mathrm{P}$ value is defined when compare SSc patients with disease onset after 45 years and controls. 
Abbre viations: $\mathrm{n}$ : number of cases, P1: $\mathrm{P}$ value was determined by the $\chi^{2}$ test comparing each group (PM,DM,SSc) and controls. P2: P value was determined by the $\chi^{2}$ test comparing positive/negative feature and comparing each feature and controls; Pc.: P value corrected for mu ltip le comparisons (3 detected genotypes, 2 alle les), ns - not significant, ANA: Antinuclear antibodies, Jo-1: antibodies against histidyl-tRNA synthethase, Scl-70 antibodies against DNA topoisomerase I, $1 \mathrm{SSc}$-limited cutaneous SSc, dSSc-d iffuse cutaneus SSc, CPM: cancer associated Polymyositis, CDM: cancer as sociated Dermatomyositis 